\title{
A CDA Perspective of Cultural Contents in the English Junior High School Textbooks
}

\author{
Vidya Mandarani ${ }^{1}$, Oikurema Purwati ${ }^{2}$, Dian Rahma Santoso ${ }^{3}$ \\ ${ }^{1}$ Universitas Negeri Surabaya, Universitas Muhammadiyah Sidoarjo, Indonesia e-mail: \\ vidya.20002@mhs.unesa.ac.id \\ 2Universitas Negeri Surabaya, Indonesia.e-mail: oikuremapurwati@unesa.ac.id \\ 3 Universitas Muhammadiyah Sidoarjo, Indonesia.e-mail:dianrahma24@umsida.ac.id
}

\begin{tabular}{|c|c|}
\hline ARTICLE INFO & ABSTRACT \\
\hline $\begin{array}{l}\text { Keywords: } \\
\text { CDA, cultural contents, } \\
\text { cultural value, english } \\
\text { textbook }\end{array}$ & $\begin{array}{l}\text { In the aim to engage the volatile future, Kemendikbud considered developing } \\
\text { the textbooks with cultural values imbued for the } 2013 \text { Curriculum. This study } \\
\text { is a content analysis that seeks to examine the cultural elements found in the } \\
\text { English textbooks for junior high schoolers, to discover the evidence of global } \\
\text { cultural manifestation in the textbooks, as well as to find out the space given } \\
\text { to local culture in the textbooks. The data were collected from the latest } \\
\text { revision of 'When English Rings a Bell' textbook for both } 7 \text { th \& 8th grade, and } \\
\text { 'Think Globally Act Locally' textbook for gth grade. The data then analyzed } \\
\text { qualitatively. The findings showed that: (1) social group \& social identity } \\
\text { dictate the cultural dimension, followed by belief \& behavior. While another } \\
\text { aspect, such as stereotypes \& national identity, social interaction, the life- } \\
\text { cycle \& socialization, national culture heritage, national geography, national } \\
\text { history as well as socio-political institution, are not commonly presented. This } \\
\text { idea is in line with the curriculum objectives to facilitate the development of } \\
\text { students with proper character, behavior and a strong sense of nationality. In } \\
\text { terms of proportionality as shown by cultural dimensions, it is inferred that } \\
\text { the English textbooks are on their way to perfection; (2) the existence of the } \\
\text { target cultures is still dominant, yet the authors had tried to maintain the } \\
\text { initial content of the source culture, as well as (3) the students require to } \\
\text { realize the importance of learning culture from their English textbooks \& } \\
\text { develop their cultural competence and a certain degree of respect, as well as } \\
\text { tolerance for others. }\end{array}$ \\
\hline
\end{tabular}

How to cite:

Mandarani, V., Purwati, O., Santoso, D. R. (2021). A CDA Perspective of Cultural Contents in the English Junior High School Textbooks. Indonesian Journal of English Language Teaching and Applied Linguistics, 5(2), 237-250.

\section{Introduction}

The ever-changing nature of human lives created an opening for a disruptive age of globalization, where future challenges that previously unknown lies ahead of Indonesian next generation. The rise of creative and cultural industries is a few among others. These changes 
urge the development of a nation's educational curriculum as a solution to these hurdles. By the regulation No. 79 of 2014, the Indonesian Ministry of Education and Culture (Kemendikbud) formed an effort to integrate cultural values into any form of learning and teaching activities, assuming students might identify, hence further appreciate their environmental, cultural, social, and to some extent, spiritual values; as well as to preserve and develop their local wisdom that will further enhance their national identity (Kemendikbud, 2014b). To attain the objective of character-based education through textbooks (Ariawan, 2020), Kemendikbud then published the official textbooks for elementary to senior high schoolers. Textbooks are one of the materials that underwent various changes since the latest 2013 curriculum.

Thus, the textbooks ought to be designed with a suitable context. Not only it will support a successful teaching and learning process, but it will also represent Indonesian diverse culture, which later gets contextualized in an English language learning environment. Furthermore, textbooks are considered a medium where, not only a transfer of knowledge, yet something grander than that like specific ideology circulation or empowerment of a particular belief, happens. This is proven since textbooks are regarded as one of the media where social dominance is implicitly wielded (Da Silva, 1999).

Above all else, textbooks also include visual work like images and pictures. The term 'language' itself will be used to represent mostly the usual sense of verbal languages, such as words, sentences, and the likes of them (Fairclough, 2003). Text may primarily present changes in our attitudes, beliefs, knowledge, values, and so forth. Indonesia is known as a heaven of diversity since there are numerous ethnics, customs, norms, and other cultural practices (Rizky \& Wibisono, 2012). To nurture cultural awareness along with language competence, the materials ought to provide more than a symbolic credit of cultural identity (Pulverness, 2014). Cultural content is crucial in the compounding of a proper EFL textbook and developing cultural awareness in the mind of EFL learners (Bahrami, 2015).

Cortazzi \& Jin (1999) suggested a different approach to integrating proper cultural contents into language textbooks. It involves the three elements, namely sources culture, target culture, and international culture. Source culture refers to learners' own culture that they are familiar the most with; target culture implies the culture from countries with English as its native or national language (i.e., the cultures of US, New Zealand, UK); whereas international culture addresses the variety of cultures from around the globe. The aim of cultural depiction in every EFL textbook should contain a proportional amount of these types of culture. It is advised not to make target culture become dominant over the others in EFL textbooks for the sake of accustoming new cultural insights for both teacher and learners (Hermawan \& Noerkhasanah, 2012).

Considering the importance of English, most Indonesian started to learn the English language effectively since junior high. This fact strengthens the importance of preparation for textbook content in compliance with the emphasis upon the notion of language-and-culture by various scholars (Chapelle \& Risager, 2013; Raigón-rodríguez, 2018). This research is mainly fuelled by the preceding research findings, which unveiled the cultural contents in EFL textbooks issued by Kemendikbud. First, Hermawan (2012) discovered that the target culture is more prominent \& widespread in 'Grow with English' textbook for $4^{\text {th }}$ to $6^{\text {th }}$ grader of primary school. Second, Syahri \& Susanti (2016) exhibited that 5 out of 9 Top Notch textbooks series 
for junior high school have a higher percentage of local culture embedded in its reading material, whereas the target culture is more eminent under picture analysis. Both studies employed Cortazzi \& Jin's theory to highlight what culture dominates the textbooks' content. Afterwards, Mayangsari et al. (2018) found that perspective and products (artefacts) have dominated the textbook for $8^{\text {th }}$ grader entitled 'When English Rings a Bell'; As for its $7^{\text {th }}$ grader counterpart, Qodriani \& Kardiansyah (2018) discovered that the embedded local culture in the textbook exists solely to enhance both teachers' \& students' awareness upon the correlation of language \& culture. The last study, conducted by Ariawan (2020), in which he investigated the stereotype \& national domination in a cultural domain, as well as the use of target \& international culture in nurturing students' respect, tolerance, and cultural competence.

It is also fascinating to found that there is only a few to none local studies that investigate the revised edition of EFL textbooks for junior high school since those prior studies concerned with the pre-revision version of 'When English Rings a Bell' \& 'Think Globally Act Locally' textbooks. As we have currently known, the textbook has since revised twice since 2014 . Additionally, researchers regarded the textbooks to play a significant role in knowledge formation in a socio-cultural context of the language classroom \& aimed to address the textbook analysis from a critical perspective. This research is designed under 3 main objectives, namely: 1) to analyse how cultural value is represented in the latest version of the English textbook of 'When English Rings a Bell' for $7^{\text {th }} \& 8^{\text {th }}$, as well as 'Think Globally Act Locally' for $9^{\text {th }}$ grade of junior high school in Sidoarjo by employing Byram's categories (1989, 1994); 2) to discover the evidence of global cultural manifestation in the textbooks; as well as 3) to find out the space given to local culture in the textbooks.

\section{Literature Review}

\subsection{Critical Discourse Analysis (CDA)}

Language has long known inseparable to the member of society in which it is spoken, which is why language is tightly correlated to its speakers' culture and speech's culture (Downes, 1998; Jourdan \& Tuite, 2006). In such a case, no wonder a specific circumstance dictates the use of a specific language. Regarding such fact, critical discourse analysis (further shortened as (DA) emerged as one of the dominant approaches in examining discourse and culture (Roohani \& Heidari, 2012). Janks (1997), mentioned that CDA originated from a critical theory of language that saw language usage as a kind of a social practice, which further tied to a certain degree of specific historical context and by which the existing social relations are formed or clashed and different interests are displayed. Thus, CDA is created when an analysis seeks to understand how a discourse relates to power.

Fairclough (1995) stated the 3-dimensional framework of CDA, which consist of text, discourse practice, and socio-cultural practice. Each of these is connected to another 3 interrelated analysis process, namely: the analysis object, which is in the shape of verbal, visual, and visual texts; the object production processes that can be in the form of writing, speaking, designing, and reading, listening; as well as humans' perspective or socio-historical conditions that rule those processes. In short, these dimensions entail different kinds of analysis: text analysis (description), processing analysis (interpretation), and social analysis (explanation). The order in which analysis is used first does not matter so long as all of them are included and are mutually shown explanatory (Janks, 1997). 
Norman Fairclough in his work the Textual Analysis for Social Research (2003), stated that text does not need to be linguistic at all since any cultural artefacts - pictures, sounds effects, virtually anything - can be seen as a text in cultural analysis. As for textual analysis, one will analyse the text's texture, structure, form, and organization. For socio-cultural analysis, textual evidence may enrich the analysis, hence why it is partly linguistic and intertextual at the same time. Contrary to textual analysis that provides insight on what is in the text, the socio-cultural analysis gives insight on what's missing from a text. The insight found in a text can be in an implicit or explicit form, which is quite pivotal in socio-cultural analysis, since what's implied in a text often give the way into an ideological analysis of a text (Fairclough, 1995).

It possesses causal effects and may contribute to changes in people (attitudes, beliefs, etc.), social relations, actions, and world material. The ideological effect, including the impact of text sustaining and instilling or altering ideologies, is one of the causal effect's examples. An ideological representation can be distinguished in text, yet it can be shown to promote the social relation of domination and power (Fairclough, 2003).

\subsection{Cultural Content of Textbook}

McGrath (2002) defined that aside from presenting relevant cultural content, textbooks carry it, whereas linguistic contents are mostly displaying intrinsic ideologies in EFL context from a specific aspect. Culture-enhanced learning materials took references from customs, norms, symbols, traditions, and beliefs shared collectively by a community. To portray this, a certain culture may emerge from a seemingly mundane activity or something that is taking place or continuously occurred in a limited group of people in a certain region (Kawar, 2012). Aside as the counterpart of teachers' instruction, the textbook also offers valuable inputs in delivering students to cultural diversity and new cultural expression (Lund, 2006; Richards, 2001). It can also influence students' thoughts and inclinations concerning themselves, others, as well as the society (Ndura, 2004). It will affect learners' behaviours, perspectives, \& their preferred language in second/foreign language communication. Otlowski (2003) noted that the various means in which people are portrayed in communication might affect learner's viewpoints.

Integrating cultural values in teaching materials involve equivalence. Sensible consideration of cultural content is one of the standards in material development (Andarab \& Inal, 2014). Therefore, many authors have suggested the use of both cultures of local language \& target language to correspond the limitation of solely employing one of the cultures as learners need to understand their own and others' cultures (Frank, 2013); above all else, a proper textbook retains several values of character education as a building process of soft-skill acquisition (Khusniyah \& Khomsiyah, 2019).

Addressing the cultural content, Michael Byram, as one of the most renowned researchers on cultural content and intercultural learning in the context of foreign language textbooks, presented 9 cultural aspects to broadly classify textbooks that incorporate social, historical \& geographical factors. These aspects later known as Byram's categories, which comprises of: 1) social group \& social identity, which encompasses social class, minority and majority ethnic, regional identity, professional identity, and individual's social identity; 2) social interaction that entails a situation or custom utilized in a particular group of society, including verbal \& non-verbal behaviour in social interaction, different degrees of formality, and characters (outlooks, attitudes, values, \& perceived issues); 3) belief \& behaviour fixated on 
daily routines in society that involve religious \& moral values; 4 ) socio-political institutions in a particular region; 5) the life-cycle and socialization, which includes a smaller degree of organizations such as family, school, office \& group ceremonies; 6) national history that encompasses historical \& contemporary events; 7) national geography, which refers to geographical features related to a particular group of people \& their environment; 8 ) national cultural heritage, which includes artefacts and peculiar items, as well as 9) national identity \& stereotypes that refers to the landmarks of a nations and its people (Byram, 1989, 1994).

Through the presentation of various cultural values, the teacher as a role model may teach the positive side of cultural recognition towards the students. Teachers are also responsible for preserving local wisdom through the means of learning material. Hence, character education became a pivotal issue in the education domain, since it's apparent that our late education system doesn't give adequate support for students' proper moral \& character development (In-jae, 2001). Despite the fervour of character building, which has surely been embedded into the national education curriculum and plainly stated within the national education objective, as well as the wide acceptance that students' moral development as one of the initial aims of formal education, it is only in these recent times that character-building issue amassed various public concerns (Aslan \& Setiawan, 2019; Kirschenbaum, 1995). Such an extraordinary concern upon character building is proportionally caused by the negligible implementation of character development in Indonesia. It is marked by the regarded poorlymannered characters that are apparent today throughout the country, manifested into numerous misdeeds such as corruption, intolerance, adultery, and violence (Nadhif, 2017). Therefore, elements of morality and cultural values must be included within the textbook's contents to minimize the impact of acculturation that may alter students' living style as well as inflict moral crisis upon the next generation.

\subsection{CDA for Textbook Analysis}

Below are the studies that employed the same approach of CDA to examine cultural content imbued in the EFL textbooks. First is Akincioglu (2012), who investigate the content of EAP Now! and Oxford EAP textbooks. These textbooks differ in several authentic texts that contain iconic ideological \& recognizable neoliberal words/discourse. This study's outcome showed that a critical approach may produce a social dimension to textbook analysis through the creation of transparent textbook content, which will reveal their ideological aspects.

The second came from Roohani \& Heidari (2012) who evaluated the Summit 2B textbook to unveil the representation of both male and female social actor. The study employed Leeuwen's (1996) social actor framework and Halliday's (2004) transitivity model. It was found in this study that there was no attempt to abolish gender biases in the textbook, despite both males and females are almost undetermined and informalized. They also advised both publisher $\&$ writers to be more cautious in gender discourse.

Followed by Samadikhah \& Shahrokhi (2015) attempt to discover a gender representation by holding a comparison between Summit \& Top Notch series by adopting Fairclough's (1989, 2001) model of ideology identification. The outcome showed that Top Notch presented a more balanced representation in contrast to Summit series. Hence, this study helps us in gaining a better perception of textbooks that are currently in use by Iranian language institutes. 
Further, Nadhif (2017) also analyzed the representation of moral values \& religion in a textbook of When English Rings a Bell for $7^{\text {th }}$ grade of junior high by employing Fairclough's $3^{-}$ dimensional models. The finding showed that the textbook indeed displayed a certain degree of moral values and religion, as well as an idea of woman emancipation by the feminist movement. Whereas Beiki \& Gharaguzlu (2017), who employed textual analysis of the CDA approach in investigating the linguistic representation of male \& female social actors in American English Files as well as to unearth the implied ideology, has found that the textbook mainly focused on uncontroversial issues. The textbook was also shown to represent the culture (or discourse) of western countries, which may display specific ideologies on language learners.

The abovementioned studies employed different CDA framework dimensions. Form the outcome, it can be inferred that the textbooks in English-speaking countries have displayed ideological aspects, whereas there's yet a balanced gender discourse in the EFL textbooks setting. Similarly, this research utilized the same Fairclough's $(1995,2003)$ model to unveil the ideological aspect beneath the cultural contents in the official textbooks issued by the Indonesian Ministry of Education and Culture.

\section{Research Methodology}

This research has a descriptive qualitative design, which employed content analysis as the analytical technique, which is suitable for systematic, objective, and description of 'manifested' content in a text (Hsieh \& Shannon, 2005). The text itself came in a variety of words, phrases, or sentences. The analyzed target can be in the form of writing as in books, spoken as in movies or films, or visually portrayed as in documents or pictures. The analysis is based on Byram's $(1989,1994)$ categories, which further followed by a CDA of text across the description, interpretation, and explanation process (Fairclough, 1995, 2003). This way, the description of the collected data will assist ground interpretation on how the discourse (re)constructed by the text that may, either implicitly or explicitly, lead to different discourses, as well as enable indicating misinterpretation, which plays a significant role in knowledge formation. Lastly, a critical analysis may be added, which may connect the text \& discourse in a wider social and cultural context.

\subsection{Data Source}

The data of this research are extracted from the revised edition of an official students' English textbook for Indonesian students in secondary school, entitled 'When English Rings a Bell' (2016) for $7^{\text {th }}$ grade; 'When English Rings a Bell' (2017) for $8^{\text {th }}$ grade, as well as "Think Globally, Act Locally" (2018) for $9^{\text {th }}$ grade. These 3 books are issued by the Indonesian Ministry of Education \& Culture.

\subsection{Data Analysis Procedures}

Such circumstance requires the researchers to read 3 distinct books with 646 pages in total, as well as classifying words, pictures, and reading passages. Regarding the CDA perspective, researchers conducted a textual analysis based on Byram's categories. Afterwards, the process continues to interpreting each category to unveil the global cultural manifestation evidence in the textbook. Lastly, a critical analysis is an elaboration on how much spaces are given to local culture in the said textbooks. 


\section{Findings and Discussion}

\subsection{Description of Cultural Contents in the Textbooks}

Researchers have compiled the cultural contents from the said three textbooks and describe them to reach the $1^{\text {st }}$ objective. The findings are divided into nine categories: social identity \& social groups, social interaction, belief \& behavior, socio-political institutions, the life-cycle and socialization, national history, national geography, national cultural heritage as well as stereotypes, and national identity.

\section{a. Social groups \& social identity}

Despite this category covers social class, regional identity, and ethnic minorities, the researcher may only find several types of regional identity. The first, it is presented through the choice of main characters' name. 2 out of 3 textbooks used the same name for male characters, such as Edo, Gunawan, Tito, Beni, Udin, as well as Siti, Yuli, Dewi for females. These names are also further visualized, which examples can be found in the entire pages in the form of illustration or simple reading text in the $8^{\text {th }}$-grade textbook p. 76 and $7^{\text {th }}$-grade textbook p. 176.

Second, regional identity is boldly emphasized with the mention of several Indonesian public transportations, like ojeks, angkots, becaks, bentors, andongs/delmans. These are local transport around cities and tows and still, that can be found in several regions of SouthEastern Asian, like Philippine or Thailand though under different names. These texts can be found in the $8^{\text {th }}$-grade textbook p. 78 .

Additionally, the researchers found the mention of two popular Indonesian folktales, Malin Kundang and Sangkuriang. 'Malin Kundang' is a renowned Nusantara folktale from the West Sumatera region, which can be found on $9^{\text {th }}$-grade textbook p. 135-138; whereas 'Sangkuriang' is one of Nusantara folktale from West Java region that can be found in $8^{\text {th }}$. grade textbook p. 128.

The last, it is inserted in introducing culinary of Indonesia: [pandan], [urap], [kangkung, kencur], [gorengan], [sate, lemper, pempek, kerupuk], [fried kepok, sambel uleg]. Cuisines are widely available in almost all regions of Indonesia. Some are even acknowledged as a typical dish from a certain culture. These examples are embedded in the gth grade textbook in $\mathrm{p}$. 13$14,66-67,102,147,192-193$ in the form of reading text.

\section{b. Social interaction}

This is represented in the textbook through different levels of formality in calling friends, parents or state civil apparatus. The use of honorifics, such as Ma'am, Sir, Mr., Mrs., Ms., a title conveys esteem, courtesy, or respect for position when used in addressing a person. Honorifics can be used as prefixes or suffixes depending on the appropriate occasion and presentation by style and customs. These examples can be found in the th grade textbook p. 5 in the form of verbal and non-verbal communication. In conversation analysis, the researchers found that the schoolgirl called the police 'Sir'. Further details, it can be found in the $7^{\text {th }}$-grade textbook p. $4-8,10-17,44,128,146-147,153 ; 8^{\text {th }}$-grade textbook p. 4-7, 11-15, $17,28,47,49,58,144$, as well as $9^{\text {th }}$-grade textbook p. 2-4. The inclusion of these contents aims to provide a clear picture of how people conduct verbal and non-verbal communication. As a result, learners may understand linguistically and used it in the proper context. 


\section{c. Belief and Behaviour}

This section presents morals, religious beliefs, and daily routines. The shown examples of these moral values are conveyed through several parts in form of acts of politeness, friendliness, caring, apology, and respect for someone or something. The first example is about the moral value which is represented through the gratitude expression 'thank you' and 'thanks' that can be found in the $9^{\text {th }}$-grade textbook $p$. 11 . These expressions are viewed as politeness markers, and similarly, Indonesian will often express their gratitude with 'terima kasih' or 'makasih' as a reply after getting compliments (Rachman \& Kinanti, 2018). By embedding these expressions, it shows that the materials have fulfilled the standard in providing the example of becoming a civilized human in accord with the 2nd principle of Pancasila.

Second, these are examples of concern among fellow human beings, as shown by displaying a picture of a boy assisting his dad ( $7^{\text {th }}$-grade textbook p. 91) in the form of visual illustration, and depicting affection on an ill friend ( $9^{\text {th }}$-grade textbook p. 95) through both conversation text and visual illustration, as well as visiting orphanage ( $9^{\text {th }}$-grade textbook p. 95) through a conversation text, which those are deemed as a kind of activities that entails a sense of caring.

The representation of religious beliefs is embedded in the form of thankful expressions \& portraits of families who recite supplication. The following is an utterance spoken to someone, indicating that they are thankful to God for their good fortune. The phrase 'Thank God' exhibits a religious manner of an individual who realizes the necessity of being aware of God's favour. For instance, Muslims are known to say 'Alhamdulillah' or 'Puji Tuhan' for Christians as a peculiar expression of gratefulness. In this context, the expression is said once the given assignment is accomplished by the students. This can be found in the $9^{\text {th }}$-grade textbook p. 12 in the form of conversation \& visual illustration.

Additionally, the portraits of families recite supplication. There is quite a slight difference in the form of recitation from the Muslim family snd the general family, which can be recognized by the use of the head veil (jilbab). Both are showing the gesture of praying before having breakfast, supper, or dinner together. The visual illustration can be found in the $7^{\text {th }}$-grade textbook p. 39 and p. 91.

The daily routines are represented by the customs of hand-shaking and kissing the elder's hand as leaving permission, and the portrays neighborhood life. The first example is about to leave permission. According to Novita et al. (2020), hand-shaking and kissing an elder's hand is non-verbal behavior of parental culture maintenance. Also, this act of showing respect to the parents, teachers, community, or religious leaders, Indonesian people do this culture in their daily life. The visualization of hand-shaking and kissing elder's hand are inserted in the $7^{\text {th }}$-grade textbook p. $5,7,11,182-183$ in the form of conversation \& visual illustration. Whereas the portraits of neighborhood life visualized by the picture of a certain pair of neighbors, as represented by native characters of Mr. \& Mrs Adnan, greeted another pair of neighbors, which characterized by non-native characters of Mr. \& Mrs Smith. This occurrence ubiquitously happens almost anywhere, which emphasizes friendliness upon the fellow human being, as illustrated in the $7^{\text {th }}$-grade textbook on p. 8 . 


\section{d. Socio-political Institution}

This category includes state institutions, health care, law \& order, social security, and local government. However, the researcher only found the representation of a state institution, which is 'Posyandu'. 'Posyandu' is an acronym of Pos Pelayanan Terpadu (Integrated Service Post) in Indonesia, which is purposed to improve child survival and development. The word 'posyandu' can be found in the $9^{\text {th }}$-grade textbook on p. 82 in the shape of conversation and visual illustration. This clearly shows how the social and political aspects are incorporated into the textbook.

\section{e. The Life-cycle and Socialization}

The researchers only found one example that represented the employment of teacher civil servants in the $7^{\text {th }}$-grade textbook p. 12. It can be identified through an illustration of the teacher's uniform. It is based on Domestic Ministerial Regulation (Permendagri) No. 6/2016, which discussed the uniform for civil servants in local government; every Monday, they must wear a khaki-colour uniform.

\section{f. National History}

This category includes historical and contemporary events seen as markers of national identity. In the $8^{\text {th }}$-grade textbook, p. 127, the researchers found a historical representation in a text by mentioning the local currency of Indonesia, Rupiahs or IDR. Assimilating national history in the EFL textbook may enable learners to familiarize themselves with their own culture and other cultures. This may also nurture learners' awareness of the importance of taking a lesson from them.

\section{g. National Geography}

In the $7^{\text {th }}$-grade textbook, p. 168 , there is a text that mentioned cities in Indonesia Island. It showed that Indonesian students must be able to mention the names of Indonesian provinces. Province/Cities/Islands in Indonesia: [West Sumatra, Padang; East Nusa Tenggara, Kupang; Seram Island, Medan; Central Kalimantan, Palangkaraya; West Java, Bandung; South Sulawesi, Makassar, North Kalimantan, Bulungan; Biak, Papua], [Bali], [Asia \& Australia, Pacific Ocean, Indian oceans]. The presentation of the geographical aspect is pivotal in providing learners with enough information. This can be used as material for teaching descriptive or narrative text in the EFL teaching-learning context.

\section{h. National Culture Heritage}

In the $9^{\text {th }}$-grade textbook, several conversations talked about some of Indonesia peculiar items. For instance, traditional cloth from the Batak culture is known as ulos, and the others are [keris], [angklung], [noken], [payung geulis]. These items are known as a cultural signature in Indonesian heritage and can be found on p. 149-150.

i. Stereotypes and National Identity

It is about 'typical' symbols of national identity and stereotypes. In the $7^{\text {th }}$-grade textbook, $p$. 31, there's a text of someone's profile. That someone is named Yohannes \& he lives in Biak, Papua. His visualization came with dark skin and curly hair. As we know that Papuans are familiar with the term 'Prancis' which is an acronym for Peranakan Cina Serui. They belong to the extended family of "White Papuan" or "Straight hair Papuan". This generation itself is 
known as the "Chinese Papuan". However, in this example, the people of Biak are predominantly Melanesians, whose main religion is Christianity, and they have a dark skin tone.

In conclusion, several cultural contents are connected to Indonesian local culture. In the $1^{\text {st }}$ category, we found some regional identities in 'When English Rings a Bell' textbook to present the emphasized characteristic of Indonesian. The $2^{\text {nd }}$ category showed the use of a different degree of formality in calling friends, parents, or civil servants, which gives a clear picture of how people conduct verbal and non-verbal communication that is easily found in 'Think Globally Act Locally' textbook. The $3^{\text {rd }}$ category showed some acts of politeness, sociability, caring, apology, and respect towards something/someone. It is necessary to display how students should behave. As for the $4^{\text {th }}$ category, it is represented by the word 'Posyandu' in 'Think Globally Act Locally' textbook that is a social institution whose role is to maintain public healthcare service.

Afterward, the image of state civil servants' uniform to display the students the characteristic of a civil servant, whereas national identity was also highlighted using Indonesian currency. Further, the mention of geographical aspects is important to get the students familiarized with Indonesian regions. Aside from that, several national items are introduced in the 'Think Globally Act Locally' textbook. In the last section, a character portrayal of a boy is in line with the background setting of the character (his hometown).

\subsection{The Interpretation of the Textbooks' Cultural Content}

From the description mentioned above, the cultural content presentation in the textbook, which is in the form of direct speech, text, and visual image, is embedded vividly. Cortazzi \& Jin (1999) stated that a textbook should comprise 3 different cultures, namely source culture, target culture, and international culture. Kawar (2012) added cultural values in learning materials by embedding the beliefs, customs, norms, symbols, or traditions that are shared by a societal group. To portray this, a culture may arise from a seemingly ordinary activity or something that is occurred continuously (routine) in a limited group of people in a specific region. The contents found in those three textbooks are mostly Indonesian local culture, despite not covering all categories. The eminent source culture is represented by addressing typical Indonesian names in the main characters, as well as giving a reading passage of national artifacts in the foreign language textbook. Such a presentation will lead the students in developing their English language competence without hampering Indonesian cultural values.

Additionally, learning English is not entirely separate from the exposure of the culture from English native speakers. In an English-speaking context, there is no difference between the greetings for young people to adults or young people to their peers. In contrast to that, Indonesian greetings are adjusted on a different degree of formality depending on the age levels and sometimes social disposition. As for the language textbooks, the values of the target culture cannot be unincorporated. Regarding the 2nd research objective, the content of international culture is displayed implicitly. Though the mention of public transportation as shown in 'When English Rings a Bell' textbook for $8^{\text {th }}$ grade may also be found in most South-eastern Asian nations, like the Philippines or Thailand. Furthermore, the researchers could not find another international cultural value in the textbooks for both $7^{\text {th }} \& 8^{\text {th }}$-grade students. 
The cultural contents in those textbooks also represent the reflection upon one's own culture since the materials exposed more of Indonesian cultures compared to the target culture. The inclination towards source culture discovery rather than the target culture may hinder students' competence to understand, adapt, and integrate themselves into the target culture. Thus, English textbooks are supposed to facilitate learners in experiencing the target culture for the sake of intercultural competence enhancement. Chao (2011) argued that an equal proportion of source culture, target culture, and international culture on textbook material is necessary. This way, students will not feel overwhelmed when dealing with some cultural conflicts during the process of intercultural communication. It is highly advised for the teacher to improvise by adding supplementary materials related to both target and international culture in assisting students in gaining intercultural competence.

\subsection{The Cultural Explanation of the EFL Textbooks}

The main parts of culture stemmed from the logically reformulated definition, such as values, norms, institutions, and heritage items (Zarei \& Khalessi, 2011). The values consist of ideas regarding the crucial aspects of life. These aspects are known through the subjects and topics spoken in each unit from the selected textbooks, indicating an idea of life. The value analysis, which is parallel with the analysis of target culture (Western) interpretation, is inseparable due to the attachment of language social function. Once this acculturation is inevitable, cultural extinction looms over the future generation of many Indonesians (Setiawan, 2014, cited in Aslan \& Setiawan, 2019).

Concerning the last research objective, the revised edition of EFL textbooks for junior high schoolers have much space for local culture compared to the unrevised version. In law no. $79 / 2014$, local content is considered as material about the local uniqueness and potential, which is intended to shape students' comprehension of the distinction and wisdom of their living region. It is coherent with law no. 20/2003 stated the developed curriculum that should encourage Indonesian students to be productive, creative, innovative, and effective through the reinforcement of integrated attitudes, skills, and knowledge (Kemendikbud, 2014a). Therefore, the revised version of the selected textbooks has embedded more source culture in comparison to the global culture.

The norms entail expectations on the way a person acts in different situations. This social analysis can be discovered through textual analysis on the content of religious beliefs \& behavior. The chosen textbooks have been conceptualized to include solid religious values to nurture students' character, such as reciting supplication, visiting orphanages \& uttering 'thank God' as a thankful expression to God. This finding reinforces the notion of the national education curriculum to establish norms and moral values to nurture students' moral development.

Organizations are social structures that can transmit norms and values. The role of social analysis is likely to know the family conceptualization, which is visible in the picture of a child who performed hand-shaking \& kissed his/her parent. This is an application of values in an organization (namely, family). For office context, it is represented graphically by the uniform's colour from the teacher (civil servant) that follows the government regulation.

Heritage items refer to the peculiar stuff or aspects of material culture, which are originated from culture's norms and values. It is signified by one of the Indonesian musical instruments 
known as 'angklung'. The characters naming scheme is also very Indonesian-like. Since the Indonesian government has issued several educational materials to be employed in character education projects, including textbooks; it is worth noticing that these textbooks are crucial materials in any language classrooms. Textbooks as the primary source of cultural components, apart from giving relevant and linguistic contents, are technically exposing the intrinsic ideology within the EFL context from a specific aspect. Even now, textbooks are often the only most-accessible books for students (Altbach et al., 1991).

\section{Conclusion}

The use of cultural elements is necessary to assist students in understanding the target language. Most of the textbooks have already embedded the cultural dimension and properly elaborate on each aspect, despite the tendency on target culture. Therefore, the Indonesian Ministry of Education and Culture is obliged to represent a balanced cultural content, which comprises of source culture (Indonesian), target culture (foreign/English-speaking nations), and international culture alike, to enhance students' intercultural competence. Furthermore, such content may assist the teachers who are less experienced with the target and international culture to provide a cultural topic worth displaying. The researchers expected this study to give a better insight into the understanding of cultural content application in an English textbook.

\section{References}

Akincioglu, M. (2012). A Critical Approach to Textbook Analysis: Critical Discourse Analysis (CDA) of two EAP Textbooks. University of St. Andrews.

Altbach, P. G., Kelly, G. P., \& Petrie, H. G. (1991). Textbooks in American Society: Politics, Policy, and Pedagogy. SUNY Press.

Andarab, M. S., \& Inal, D. (2014). From English of Specific Cultures to English for Specific Cultures in Global Coursebooks in EIL Era. Journal of Education and PRactice, 5(3), 50-63.

Ariawan, S. (2020). Investigating Cultural Dimensions in EFL Textbook by Using Byram Checklist. Register Journal, 13(1), 123-152. https://doi.org/10.18326/rgt.v13i1.123-152

Aslan, \& Setiawan, A. (2019). Peran Pendidikan dalam Merubah Karakter Masyarakat Dampak Akulturasi Budaya di Temajuk. Fenomena: Jurnal Penelitian, 11(1), 11-30.

Bahrami, N. (2015). Evaluating the Representation of Cultural Elements in an In-use EFL Textbook. Advances in Language and Literary Studies, 6(3). https://doi.org/10.7575/aiac.alls.v.6n.3p.128

Beiki, M., \& Gharaguzlu, N. (2017). The Analysis of Iranian English School Text Book: A CDA Study Based on Norman Fairclough's 2001 Model. International Journal of Humanities and Cultural Studies, 4(1), 55-67.

Byram, M. (1989). Cultural Studies in Foreign Language Education. Multilingual Matters. https://doi.org/10.1080/09571739185200241

Byram, M. (1994). Teaching and Learning Language and Culture. Multilingual Matters.

Chao, T. chia. (2011). The Hidden Curriculum of Cultural Content in Internationally Published ELT Textbooks: A Closer Look at New American Inside Out. Journal of Asia TEFL, 8(2), 189-210. 
Chapelle, C. A., \& Risager, K. (2013). Culture in Textbook Analysis and Evaluation. The Encyclopedia of Applied Linguistics, 1620-1625. https://doi.org/10.1002/9781405198431.wbeal1206

Cortazzi, M., \& Jin, L. (1999). Cultural Mirrors: Materials and Methods in the EFL Classroom. In E. Hinkel (Ed.), Culture in second language teaching and learning (pp. 196-219). Cambridge University Press.

Da Silva, T. T. (1999). The Poetics and Politics of Curriculum as Representation. Pedagogy, Culture and Society, 7(1), 7-33. https://doi.org/10.1080/14681369900200055

Downes, W. (1998). Language and Society (2nd ed.). Cambridge University Press.

Fairclough, N. (1995). Critical Discourse Analysis: The Critical Study of Language. Longman Group Ltd.

Fairclough, N. (2003). Analysing Discourse: Textual Analysis for Social Research. Routledge.

Frank, J. (2013). Raising Cultural Awareness in the Language Classroom. Eric, 51(4), 2-11. http://https//eric.ed.gov/?id=EJ1020809

Hermawan, B., \& Noerkhasanah, L. (2012). Traces of Cultures in English Textbooks for Primary Education. Indonesian Journal of Applied Linguistics, 1(2), 49-61. https://doi.org/10.17509/ijal.vii2.84

Hsieh, H.-F., \& Shannon, S. E. (2005). Three Approaches to Qualitative Content Analysis. Qualitative Health Research, 15(9), 1277-1288. https://doi.org/10.1177/1049732305276687

In-jae, L. (2001). The Proper Directions and Practical Ways for Character Education in the Korean Elementary School. 2(2), 72-84.

Janks, H. (1997). Critical Discourse Analysis as a Research Tool. Discourse, 18(3), 329-342. https://doi.org/10.1080/0159630970180302

Jourdan, C., \& Tuite, K. (2006). Language, Culture, and Society: Key Topics in Linguistics Anthropology. Cambridge University Press.

Kawar, T. I. (2012). Cross-cultural Differences in Management. International Journal of Business and Social Science, 3(6), 1-3.

Kemendikbud. (2014a). Konsep dan Implementasi Kurikulum 2013. In Paparan Wakil Menteri Pendidikan dan Kebudayaan R.I Bidang Pendidikan.

Kemendikbud. (2014b). Salinan Peraturan Menteri Pendidikan dan Kebudayaan Republik Indonesia Nomor 79 Tahun 2014.

Khusniyah, N. L., \& Khomsiyah, I. (2019). Culture and Religion Value in E-English Textbook for Junior High School : A Content Analysis. Schemata, 8(1), 17-24.

Kirschenbaum, H. (1995). 100 Ways to Enhance Valves and Morality in Schools and Youth Settings. Allyn \& Bacon. https://eric.ed.gov/?id=ED414003

Lund, R. (2006). Questions of Culture and Context in English Language Textbooks: A Study of Textbooks for the Teaching of English in Norway [Universitetet i Bergen]. https://doi.org/10.18261/978-82-15-03074-6-2019-13

Mayangsari, L., Nurkamto, J., \& Supriyadi, S. (2018). Cultural Content: An Analysis of EFL Textbook in Indonesia. International Journal of Scientific and Research Publications (IJSRP), 8(11), 192-199. https://doi.org/10.29322/ijsrp.8.11.2018.p8325

McGrath, I. (2002). Materials Evaluation and Design for Language Teaching (A. Davies \& K. Mitchell (eds.)). Edinburgh University Press.

Nadhif, A. (2017). Representation of Religious and Moral Values in the English Textbook for Indonesian Junior High School: A CDA Investigation. Kodifikasia, 11(1), 79-104.

Ndura, E. (2004). ESL and Cultural Bias: An Analysis of Elementary through High School 
Textbooks in the Western United States of America. Language, Culture and Curriculum, 17(2), 143-153. https://doi.org/10.1080/07908310408666689

Novita, D., Purwati, O., Anam, S., \& Setiawan, S. (2020). Using Local Contents in English Materials: A Manifestation of Maintaining Local Wisdom in English Language Teaching. Asian EFL Journal Research, 27(4), 40-62.

Otlowski, M. (2003). Ethnic Diversity and Gender Bias in EFL Textbooks. The Asian EFL Journal, 5(4), 1-15.

Pulverness, A. (2014). Developing Materials for Language Teaching (B. Tomlinson (ed.); 2nd ed.). Bloomsbury.

Qodriani, L. U., \& Kardiansyah, M. Y. (2018). Exploring Culture in Indonesia English Textbook for Secondary Education. Jurnal Pendidikan Indonesia, 7(1), 51-58. https://doi.org/10.23887/jpi-undiksha.v7i1.13692

Rachman, A. K., \& Kinanti, K. P. (2018). Respon Pujian Oleh Mahasiswa Multikultural (Studi Kasus dengan Tinjauan Sosiopragmatik). Belajar Bahasa: Jurnal Ilmiah Program Studi Pendidikan Bahasa \& Sastra Indonesia, 3(1).

Raigón-rodríguez, A. (2018). Analysing Cultural Aspects in EFL Textbooks: A Skill-Based Analysis. Journal of English Studies, 16, 281-300.

Richards, J. C. (2001). Curriculum Development in Language Teaching. In European Journal of Teacher Education (Vol. 25, Issues 2-3). Cambridge University Press. https://doi.org/10.1080/0261976022000044872

Rizky, R., \& Wibisono, T. (2012). Mengenal Seni dan Budaya Indonesia. Cerdas Interaktif.

Roohani, A., \& Heidari, N. (2012). Evaluating an Instructional Textbook : A Critical Discourse Perspective. Issues in Language Teaching, 1(1), 123-158.

Samadikhah, M., \& Shahrokhi, M. (2015). A Critical Discourse Analysis of ELT Materials in Gender Representation: A Comparison of Summit and Top Notch. English Language Teaching, 8(1), 121-133. https://doi.org/10.5539/elt.v8n1p121

Syahri, I., \& Susanti, R. (2016). An Analysis of Local and Target Culture Integration in the English Textbooks for Senior High School in Palembang. Journal of Education and Human Development, 5(2), 29-34. https://doi.org/10.15640/jehd.v5n2a11

Zarei, G. R., \& Khalessi, M. (2011). Cultural Load in English Language Textbooks: An Analysis of Interchange Series. Procedia - Social and Behavioral Sciences, 15, 294-301. https://doi.org/10.1016/j.sbspro.2011.03.089 